\title{
Forecasting Fluctuations of Sold Industrial Production in Poland on the Basis of Electricity Demand
}

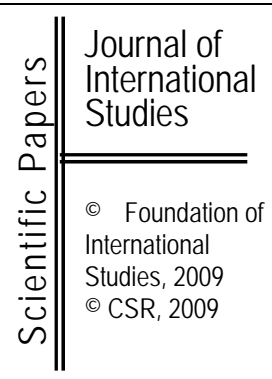

Rafał Kasperowicz

Department of Microeconomics

University of Economics in Poznań

\begin{abstract}
The plan of the paper is as follows: introduction, section 1 with the data and econometric methodology, section 2 with empirical analysis and the model, and the conclusions. Two independent equations have been estimated. Results show that significant leading time series of sold industrial production are electricity demand in four industrial sectors: production of string mass and paper, cars and metal final goods and production of machines and electric devices.
\end{abstract}

Accepted: June, 2009

Key words: Forecasting fluctuations, industrial production, electricity, Poland

JEL classification: L52, C53, P1

\section{Introduction}

Electric energy is the key production factor in the economy. It is a peculiar resource, which can not be stored. This features of electric energy cause a serious problem of estimation proper amount of electric energy which has to be supplied by producers. The focus of the paper is twofold.

First, it contains an econometric analysis of cyclical fluctuations of electricity demand and sold industrial production in Poland. Second, it presents a model for forecasting fluctuations of sold industrial production on the basis of electricity consumption. Specification of the model will be guided by the Error-Corrected Granger Causality test.

The modelling approach in this paper includes only one explanatory variable electricity demand. This article employes leading indicators forecasting method developed by the National Bureau of Economic Research (NBER). Leading indicators can be transformed into a forecast for the target variable.

The plan of the paper is as follows: introduction, section 1 with the data and econometric methodology, section 2 with empirical analysis and the model, and the conclusions. 


\section{DATA AND METHODOLOGY}

1.1. Data

The data used in this study comes from the Polish Bureau of Statistics (GUS) and Polish Energy Market Agency. Databases contain quarterly monthly observations for period from 01 quarter 1994 to 04 quarter 2004. The data are defined in table 1.

Table 1 Names of the variables used in the study

\begin{tabular}{|c|c|c|}
\hline The electricity demand by industry type in GWh & no of PKD & $\begin{array}{l}\text { Name of the } \\
\text { variable }\end{array}$ \\
\hline Mining of stone and dark brown coal; extracting of the peat & 10 & VAR1 \\
\hline Mining of ores of metal & 13 & VAR2 \\
\hline Other types of mining & 14 & VAR3 \\
\hline Production of foodstuff & 15 & VAR4 \\
\hline Textile industry & 17 & VAR5 \\
\hline $\begin{array}{l}\text { Production of wood and products of wood and from the cork (except of } \\
\text { furniture), products from the straw and the like }\end{array}$ & 20 & VAR6 \\
\hline Production of the stringy mass, the paper and products from the paper & 21 & VAR7 \\
\hline Production of the coke and products of the refinement of the crude oil & 23 & VAR8 \\
\hline Production of chemical products & 24 & VAR9 \\
\hline Production of rubber and plastics products & 25 & VAR10 \\
\hline $\begin{array}{l}\text { Production of products from other non-metallic raw materials (in it: } \\
\text { glass, bricks, cement) }\end{array}$ & 26 & VAR11 \\
\hline Production of metal & 27 & VAR12 \\
\hline Production of metal final goods except machines and devices & 28 & VAR13 \\
\hline Production of machines and devices not classified somewhere else & 29 & VAR14 \\
\hline $\begin{array}{l}\text { Production of machines and the electric machinery not classified } \\
\text { somewhere else }\end{array}$ & 31 & VAR15 \\
\hline Production of telecommunication devices, radios and TV's & 32 & VAR16 \\
\hline Production of motor vehicles, trailers and semitrailers & 34 & VAR17 \\
\hline Production of other transport equipment & 35 & VAR18 \\
\hline Furniture production & 36 & VAR19 \\
\hline Production and the distribution of electric energy & 401 & VAR20 \\
\hline Construction industry & 45 & VAR21 \\
\hline Rail transport & 601 & VAR22 \\
\hline \multicolumn{3}{|l|}{ Other variables } \\
\hline Industrial electricity demand & & VAR23 \\
\hline Sold industrial production & & VAR24 \\
\hline
\end{tabular}




\subsection{Methodology}

It is supposed that the time series contains the random component, the seasonal component, the cyclical component, and the trend. To calculate parameters all the time series must be disaggregated:

a) seasonal component and the random component must be eliminated,

b) the time series must be detrend to get pure cyclical component.

To eliminate the sesonal and the random component and find the trend-cycle decompositions from the time series the Census X-11 procedure was used. This procedure utilize some principial steps, which are ${ }^{1}$ :

1) Adjust data for trading day or holiday differences;

2) Take the resulting data and calculate a 12-month (or four-quarter) moving average;

3) Smooth this series with another moving average, usually over three or five periods;

4) Calculate preliminary sesonal factors as the actual data divided by this twicesmoothed average;

5) Identyfy the outlying values. The default option is to scale their weights from $100 \%$ to $0 \%$ when $\sigma$ is between 1,5 and 2,5 . Replace these outliers with trend values;

6) Calculate the sesonal factors based on actual data adjusted for outliers divided by smoothed trends;

7) Smooth the existing trend cycle again and recalculate the sesonal factors. In some versions, the length of the moving average chosen is longer if the underlying series has more randomness.

The statistical analysis of time series usually requires them to stationar, which is commonly done by the removal of a stochastic trend. One of the most commonly used detrending methods in recent years is the Hodrick-Prescott Filter. This method involves defining cyclical output $\mathrm{y}_{t}{ }^{\mathrm{c}}$ as current output $\mathrm{y}_{\mathrm{t}}$ less a measure of trend output $\mathrm{y}_{\mathrm{t}}^{\mathrm{g}}$, with trend output being a weighted average of past, current and future observations ${ }^{2}$ :

$$
y_{t}^{c}=y_{t}-y_{t}^{g}=y_{t}-\sum_{j=-J}^{J} a_{j} y_{t-j}
$$

The HP-filter computes a stochastic trend by minimizing the sum of squared deviations of a time series from its trend subject to the constraint that the sum of the squered second differences is not too large ${ }^{3}$. The HP filter is derived by solving the following minimization problem ${ }^{4}$ :

\footnotetext{
${ }^{1}$ Evans M.K., Practical Business Forecasting, Blackwell Publishers, 2003, p. 212-215.

2 King R.G., Rebelo S.T., Resuscitating Real Business Cycles, NBER Working Paper, 2000.

${ }^{3}$ Torben Mark Pedersen, Alternative Linear and Non-Linear Detrending Techniques: A Comparative analysis based on Euro-Zone Data, Copenhagen: Minystry of Economic and Business Affairs, 2002.

${ }^{4}$ King R.G., Rebelo S.T., Resuscitating Real Business Cycles, NBER Working Paper, 2000, and Torben Mark Pedersen, Alternative Linear and Non-Linear Detrending Techniques: A Comparative analysis based on EuroZone Data, Copenhagen: Minystry of Economic and Business Affairs, 2002, and Mills T.C., Modeling Trends and Cycles in Economic Time Series, Loughborough University, 2003.
} 


$$
\min _{\left\{y_{t}^{g}\right\}_{t=0}^{\infty}} \sum_{t=1}^{\infty}\left\{\left(y_{t}-y_{t}^{g}\right)^{2}+\lambda\left[\left(y_{t+1}^{g}-y_{t}^{g}\right)-\left(y_{t}^{g}-y_{t-1}^{g}\right)\right]^{2}\right\}
$$

where $\lambda$ is a smoothing parameter that penalizes variation in the growth component. In EViews, the defult parameters for $\lambda$ are 100 for annual data, 1600 for three months ahead data, and 14400 for monthly data.

To establish the relationship between variables the Error-Corrected Granger Causality Test was used .

Granger introduced the concept of causality for stationary series in which information about $\mathrm{X}$ is expected to affect the conditional distribution of the future values of $\mathrm{Y}$, given the "dependend" variable (Y) and X the "explanatory" variable. The granger test for causuality relies on the estimation of the bivariate auto-regressive models. To test for causality from $\mathrm{X}$ to $\mathrm{Y}$, the following model is used ${ }^{5}$ :

$$
\Delta X_{t}=\sum_{i=1}^{p} \delta \Delta X_{t-1}+\sum_{j=1}^{q} \theta_{j} \Delta Y_{t-j}+\mu_{t}
$$

where $\mu_{\mathrm{t}}$ is white noise, $\mathrm{p}$ is the order of the lag for $\mathrm{X}$ and $\mathrm{q}$ is the order of the lag for $\mathrm{Y}$. The null hypothesis that $X$ does not Granger-cause $Y$ is that $\theta_{j}=0$ for $j=1,2, \ldots q$. Thus, a rejection of the null hypothesis indicates that X Granger-causes $\mathrm{Y}$.

The next step is the estimation of the regression models. The general regression model can be written as follows ${ }^{6}$ :

$$
Y_{i}=\beta_{1}+\beta_{2} X_{2 i}+\beta_{3} X_{3 i}+\ldots+\beta_{k} X_{k i}+\varepsilon_{i}
$$

where $Y$ is the dependend variable, the $X_{k}$ are the independent variables, $\beta_{1}$ is the constant term, or intercept, of the equation, the other $\beta$ are the parameter estimates for each of the $\mathrm{X}$ terms, $\varepsilon_{\mathrm{i}}$ is the error term, and there are i observations.

\section{EMPIRIAL RESEARCH}

To calculate prameters of the econometric model time series were disaggregated. The seasonal and the random component were eliminated which lead to Henderson curve. Finally the trend was removed from Henderson curve. After this author was able to find out pure cyclical fluctuations.

\footnotetext{
5 Bennett A., Closed-End Country Found Discounds and Systematic UK and US Market movements: Cointegration and Error Corrected Granger Causality Tests, Massey University, 2002.

${ }^{6}$ Evans M.K., Practical Business Forecasting, Blackwell Publishers, 2003, p. 68-70.
} 
Figure 1. Cyclical fluctuations of the significant explanatory variables
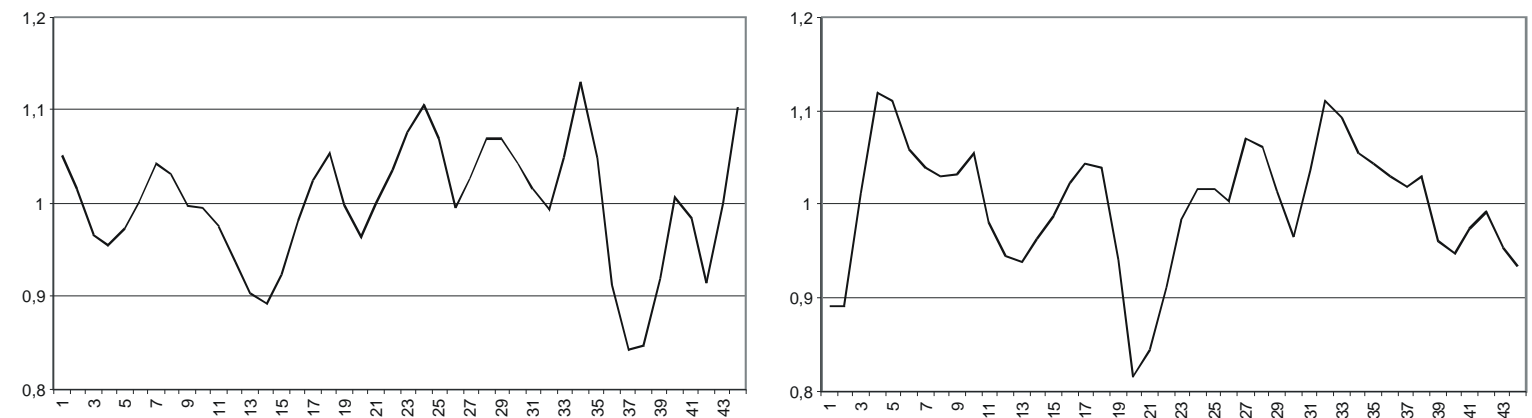

$-\operatorname{var} 7$
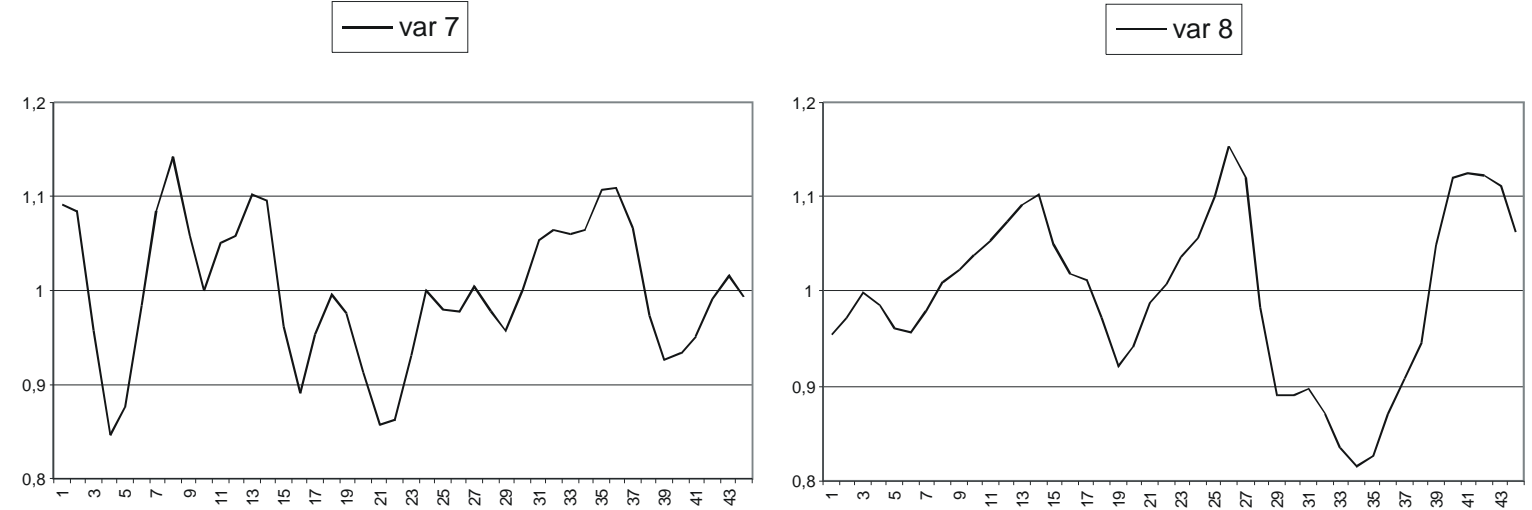

- var 13
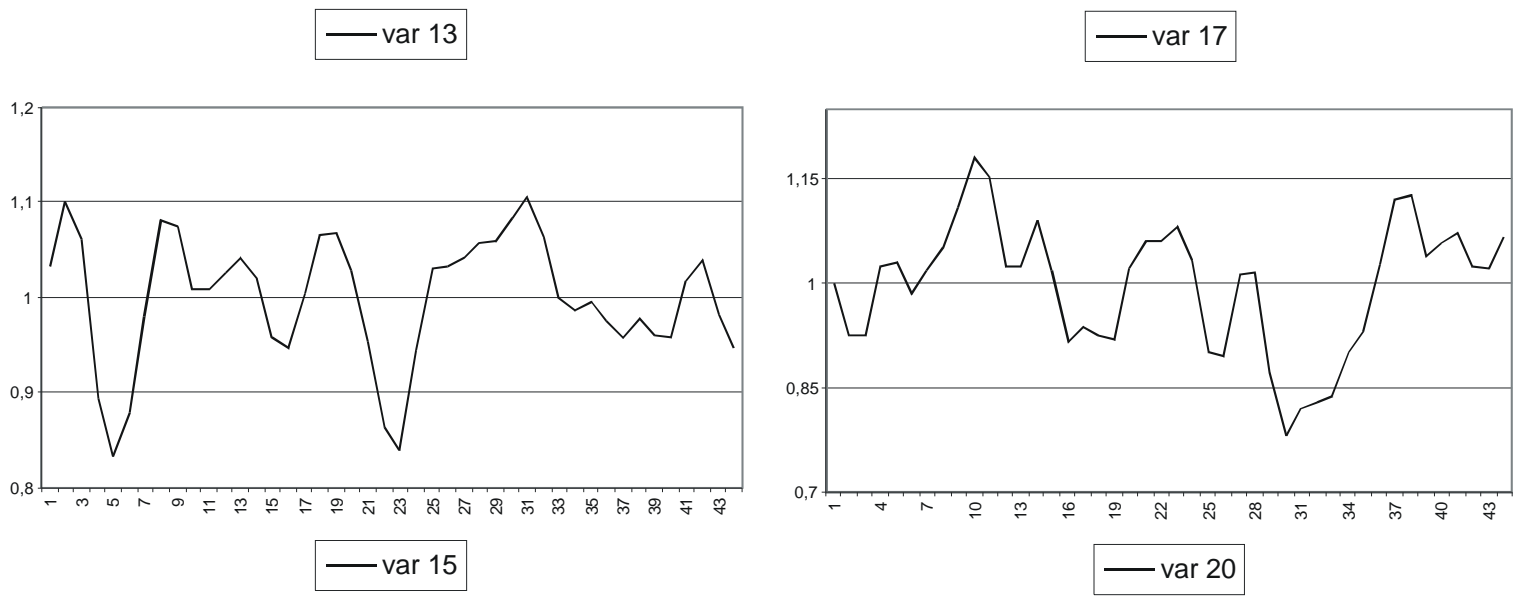

- var 15
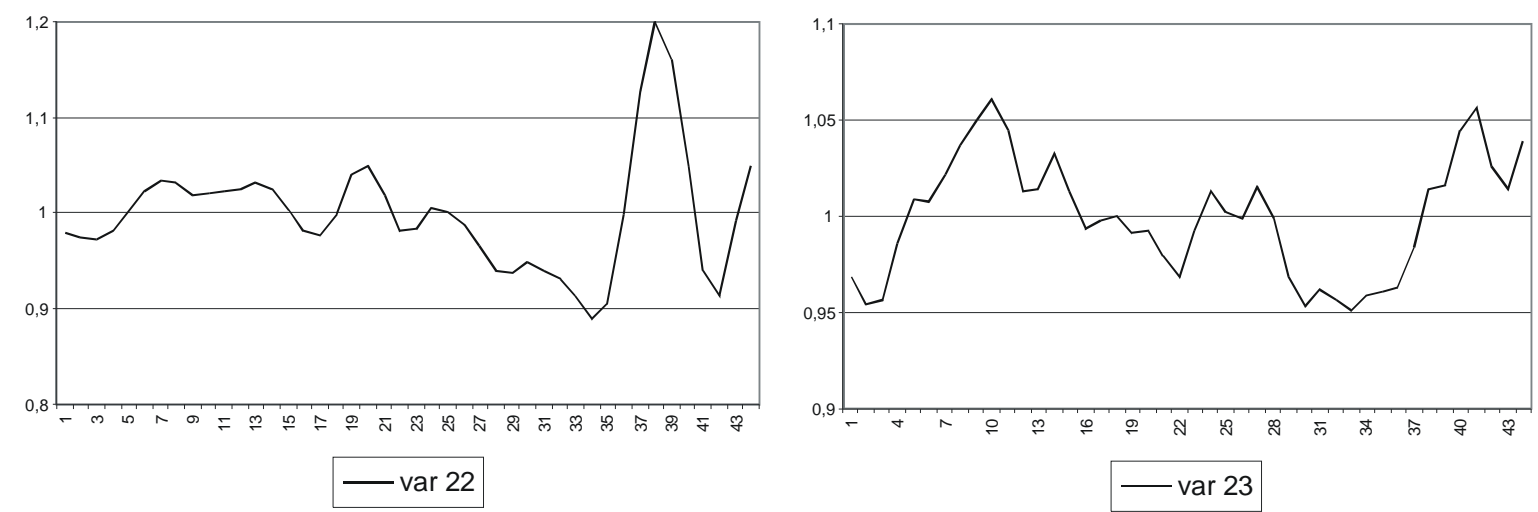

Source: own calculation. 
The next step was to conduct the Granger Causality Test to establish the dependence between variables. The leads of calculated variables measured by by the Granger Causality Test are given in table 2 .

Table 2 The significant leads of explanatory variables after Granger Causality Test

\begin{tabular}{|c|c|c|c|c|c|c|c|c|c|}
\hline \multirow{2}{*}{$\begin{array}{l}\text { dependend } \\
\text { variable }\end{array}$} & \multirow{2}{*}{$\begin{array}{l}\text { explanator } \\
\text { y variables }\end{array}$} & \multicolumn{8}{|c|}{ leads of explanatory variables } \\
\hline & & $\begin{array}{c}\text { F- } \\
\text { Statistic } \\
\end{array}$ & 1 & \begin{tabular}{|c|} 
F- \\
Statistic \\
\end{tabular} & 2 & \begin{tabular}{|c|} 
F- \\
Statistic \\
\end{tabular} & 3 & $\begin{array}{c}\text { F- } \\
\text { Statistic } \\
\end{array}$ & 4 \\
\hline \multirow{23}{*}{ var24 } & var1 & 0.06008 & 0.80763 & 1.20333 & 0.31167 & 3.47156 & 0.02658 & 3.15837 & 0.02743 \\
\hline & var2 & 0.94899 & 0.33583 & 0.81365 & 0.45101 & 1.58473 & 0.21106 & 0.63665 & 0.64024 \\
\hline & var3 & 0.52907 & 0.47123 & 1.36372 & 0.26826 & 1.82262 & 0.16162 & 1.11107 & 0.36898 \\
\hline & var4 & 0.92751 & 0.34130 & 0.12982 & 0.87865 & 0.39117 & 0.76010 & 1.19092 & 0.33429 \\
\hline & var5 & 7.73497 & 0.00822 & 0.43332 & 0.65160 & 1.00751 & 0.40137 & 0.72696 & 0.58032 \\
\hline & var6 & 0.83511 & 0.36627 & 7.33494 & 0.00207 & 12.9027 & 8.7E-06 & 9.29976 & 4.7E-05 \\
\hline & var7 & 1.91785 & 0.17377 & 4.10906 & 0.02446 & 6.02682 & 0.00209 & 3.95294 & 0.01048 \\
\hline & var8 & 1.03967 & 0.31403 & 9.77884 & 0.00039 & 3.42408 & 0.02795 & 7.26768 & 0.00030 \\
\hline & var9 & 0.00236 & 0.96149 & 3.96010 & 0.02764 & 1.68826 & 0.18791 & 1.95615 & 0.12596 \\
\hline & var10 & 0.11736 & 0.73371 & 1.80374 & 0.17886 & 1.04038 & 0.38715 & 0.18520 & 0.94434 \\
\hline & var11 & 0.02976 & 0.86392 & 0.13724 & 0.87221 & 0.02357 & 0.99500 & 0.60686 & 0.66067 \\
\hline & var12 & 0.08737 & 0.76907 & 2.00324 & 0.14927 & 0.96269 & 0.42154 & 1.33669 & 0.27847 \\
\hline & var13 & 11.0802 & 0.00188 & 3.43225 & 0.04292 & 2.18988 & 0.10720 & 2.83026 & 0.04130 \\
\hline & var14 & 1.36339 & 0.24986 & 1.21286 & 0.30889 & 0.75003 & 0.52993 & 2.13402 & 0.10020 \\
\hline & var15 & 13.0730 & 0.00083 & 0.17312 & 0.84172 & 3.51632 & 0.02535 & 4.28086 & 0.00714 \\
\hline & var16 & 3.32198 & 0.07584 & 0.52311 & 0.59699 & 0.03148 & 0.99235 & 0.43968 & 0.77893 \\
\hline & var17 & 26.9861 & $6.4 \mathrm{E}-06$ & 14.2203 & 2.6E-05 & 6.71287 & 0.00111 & 6.27776 & 0.00080 \\
\hline & var18 & 2.47513 & 0.12354 & 0.82527 & 0.44602 & 3.27018 & 0.03292 & 4.33844 & 0.00668 \\
\hline & var19 & 0.29068 & 0.59277 & 0.57856 & 0.56570 & 0.64541 & 0.59122 & 0.42219 & 0.79138 \\
\hline & var20 & 5.03064 & 0.03051 & 3.97358 & 0.02734 & 5.71986 & 0.00279 & 2.97051 & 0.03465 \\
\hline & var21 & 2.22375 & 0.14375 & 0.53880 & 0.58796 & 0.65411 & 0.58593 & 0.38095 & 0.82050 \\
\hline & $\operatorname{var} 22$ & 2.60959 & 0.11408 & 12.6777 & $6.4 \mathrm{E}-05$ & 7.32760 & 0.00065 & 3.30178 & 0.02299 \\
\hline & var23 & 4.09546 & 0.04971 & 1.88504 & 0.16612 & 2.25895 & 0.09927 & 1.84085 & 0.14613 \\
\hline
\end{tabular}

Source: own calculation. 
Figure 2. Cyclical fluctuations of the depended variable

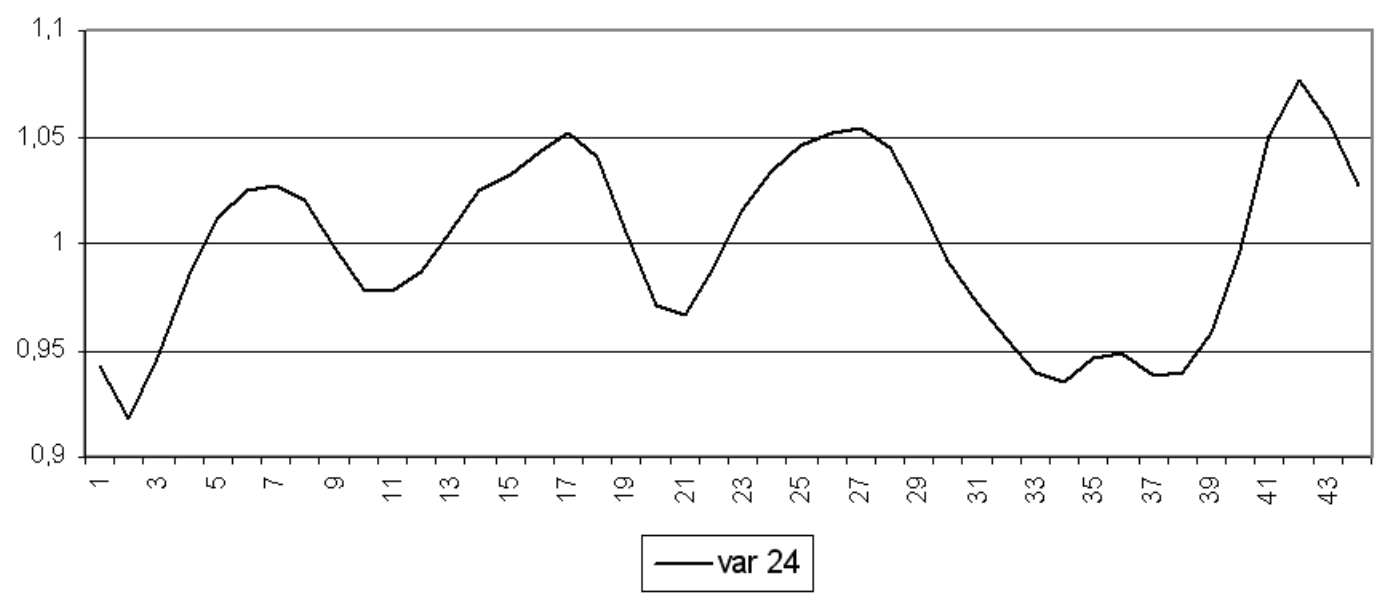

Source: own calculation.

To calculate the significant leads for the equation specificated by Granger Causality Test there were estimated regression equations for each variable given in table 2 . The results are given in table 3 .

Table 3 The significant leads of variables included to the model estimation

\begin{tabular}{|c|c|c|c|}
\hline $\begin{array}{l}\text { dependend } \\
\text { variable }\end{array}$ & explanatory variables & leads & $\mathbf{R}^{2}$ \\
\hline \multirow{8}{*}{ var24 } & $\begin{array}{l}\text { Production of the stringy mass, the paper } \\
\text { and products from the paper }\end{array}$ & 4 & 0,28 \\
\hline & $\begin{array}{l}\text { Production of the coke and products of the } \\
\text { refinement of the crude oil }\end{array}$ & 4 & 0,26 \\
\hline & $\begin{array}{c}\text { Production of metal final goods except } \\
\text { machines and devices }\end{array}$ & 2 & 0,26 \\
\hline & $\begin{array}{l}\text { Production of machines and the electric } \\
\text { machinery not classified somewhere else }\end{array}$ & 3 & 0,19 \\
\hline & $\begin{array}{c}\text { Production of motor vehicles, trailers and } \\
\text { semitrailers }\end{array}$ & 2 & 0,73 \\
\hline & Rail transport & 4 & 0,72 \\
\hline & $\begin{array}{c}\text { Production and the distribution of electric } \\
\text { energy }\end{array}$ & 4 & 0,54 \\
\hline & Industrial electricity demand & 1 & 0,33 \\
\hline
\end{tabular}

Source: own calculation.

The estimation of the main leads of variables let author to calculate the following model:

$$
\operatorname{var} 24_{q}=1,056+0,313 \operatorname{var} 17_{t-2}-0,146 \operatorname{var} 13_{t-2}-0,127 \operatorname{var} 15_{t-3}-0,92 \operatorname{var} 7_{t-4}
$$

$R^{2}=0,922, \bar{R}^{2}=0,913, F(4,35)=103,06$

var $24_{q}$ - forecast indicator of quarterly sold industrial production. 
Figure 3. Fluctuations of sold industrial production

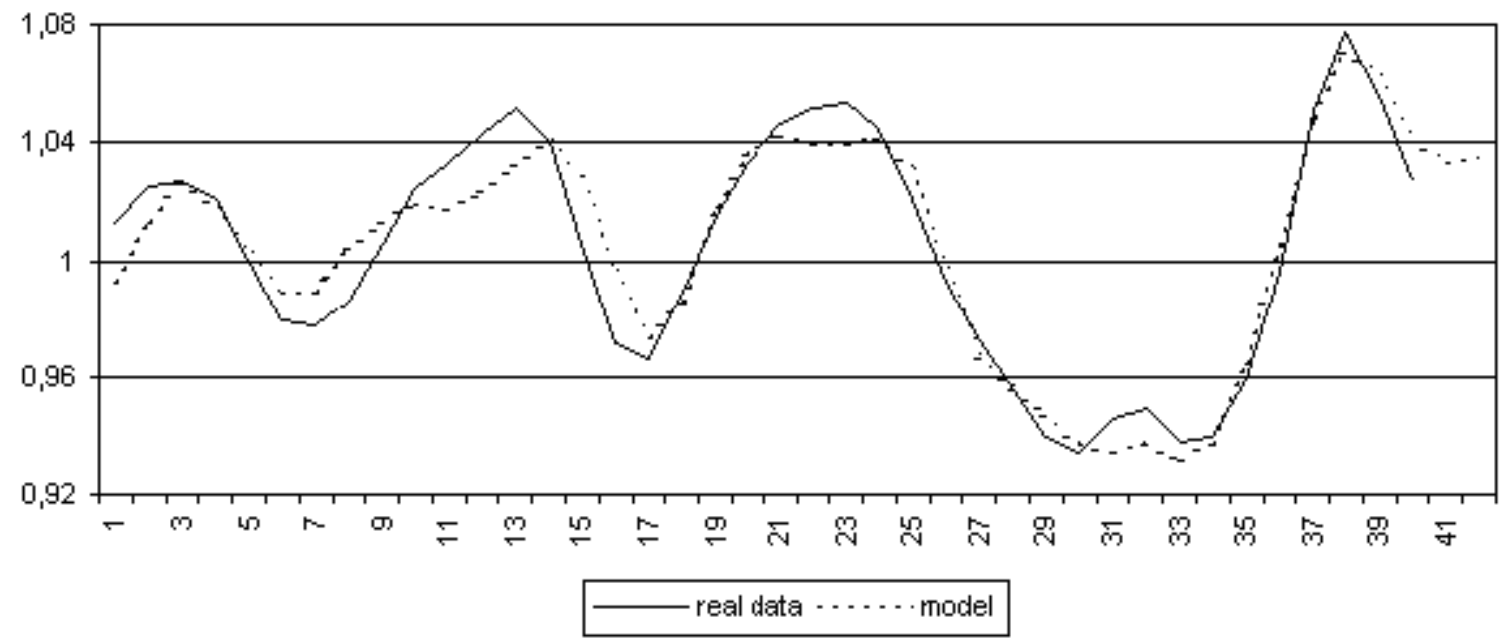

Source: own calculation.

The estimated model is useful for one or two quarter ahead forecasts because of the significant leads of explanatory variables. Very good econometric properties of model $\left(\mathrm{R}^{2}=0,92\right)$ shows that data used in the model was choosen properly and it can be useful for forecasting. Moreover forecasting ability of the model was confirmed by the ex post analysis. This attitde requires some shortening of the significant explanatory varibles time series - the four last observations of quarterly data were removed, after this a new model with the same explanatory variables was estimated:

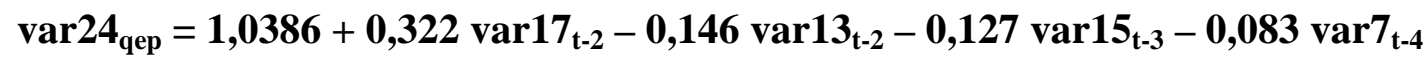

$$
\begin{aligned}
& R^{2}=0,91, \bar{R}^{2}=0,897, F(4,31)=78,031
\end{aligned}
$$

\section{Figure 4. Fluctuations of sold industrial production - ex post analysis}

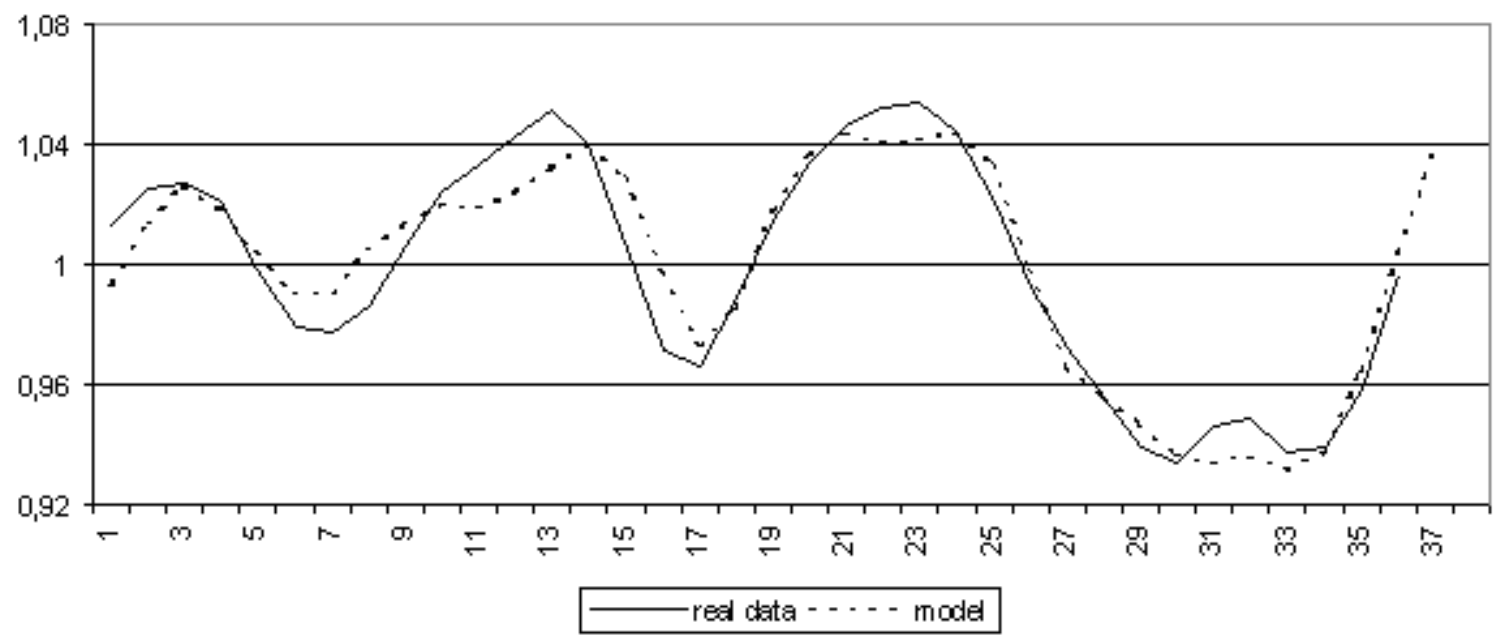

Source: own calculation. 
After analysing the figure 4. it is possible to affirm that the ex post model of sold industrial output is very good fiited to the empirical data.

\section{CONCLUSIONS}

Two independent equations have been estimated. Results show that siginficant leading time series of sold industrial production are electricity demand in four industrial sectors: production of string mass and paper (leads 4 qaurters), cars and metal final goods(both 2 quarters) and production of machines and electric devices(3 quarters). Other 18 time series turned out to be less efficient for forecasting. The estimated model has very good econometric properties and can produce trustworthy short time forecasts.

\section{REFERENCES}

1. Baxter M., King R.G, Measuring Business Cycles: Approximate Band-Pass Filters for Macroeconomic Time Series, Review of Economics and Statistics, 1999.

2. Bennett A., Closed-End Country Found Discounds and Systematic UK and US Market movements: Co-integration and Error Corrected Granger Causality Tests, Massey University, 2002.

3. Diebold Francis X., The Past, Present, and Future of Macroeconomic Forecasting, University of Pennsylvania, NBER and Federal Reserve Bank of Philadelphia, 1997.

4. Engle R.F., Granger C.W.J., Hallman J.J., Merging Short- and Long-run Forecasts: An Application of Seasonal Cointegration to Monthly Electricity Sales Forecasting, Journal of Econometrics, 1989.

5. Engle R.F., Granger C.W.J., Ramanathan R., Short-Run Forecasts of Electricity oads and Peaks, International Journal of Forecasting, 1997.

6. Evans M.K., Practical Business Forecasting, Blackwell Publishers, 2003, p. 212-215.

7. Granger, C.W.J., Some Properties of Time Series Data and Their Use in Econometric Model Specification, Journal of Econometrics, 1981.

8. King R.G., Rebelo S.T., Resuscitating Real Business Cycles, NBER Working Paper, 2000.

9. King, R.G., Plosser, C.I., Stock, J.H., and Watson, M.W., Stochastic Trends and Economic Fluctuations, American Economic Review, 1991.

10. Leth-Petersen S., Micro Econometric Modeling of Household Energy Use: Testing for Dependence between Demand for Electricity and Natural Gas, The Energy Journal, 2002.

11. Marcellino M., Leading Indicators: What Have We Learned?, IEP-Bocconi University.

12. Mills T.C., Modeling Trends and Cycles in Economic Time Series, Loughborough University, 2003.

13. Prescott, E.C., Theory Ahead of Business Cycle Measurement, Quarterly Review, Federal Reserve Bank of Minneapolis, 1986.

14. Torben Mark Pedersen, Alternative Linear and Non-Linear Detrending Techniques: A Comparative analysis based on Euro-Zone Data, Copenhagen: Minystry of Economic and Business Affairs, 2002.

15. Zarnowitz V., Braun P., Major macroeconomic variables and leading indicators: some estimates of their interrelations, 1886-1982, NBER Working Paper, 1989. 